\title{
Relaxant effects of different fractions from Tymus vulgaris on guinea-pig tracheal chains
}

\author{
Rana Keyhanmanesh ${ }^{1,2,3}$ and Mohammad H. Boskabady ${ }^{4, *}$ \\ ${ }^{1}$ Department of Physiology, Tabriz University of Medical Sciences, Tabriz, Iran \\ 2 Tuberculosis and lung research center, Tabriz University of Medical Sciences, Tabriz, Iran \\ 3 Drug applied research center, Tabriz University of Medical Sciences, Tabriz, Iran \\ ${ }^{4}$ Department of Physiology, Medical School and Pharmacological Research Centre of Medical Plants, Mashhad University of Medical Sciences, Mashhad, Iran
}

\begin{abstract}
In previous studies, the relaxant effect of Tymus vulgaris has been demonstrated on guinea pig tracheal chains. Therefore, in the present study, the relaxant effects of n-hexane, dichloromethane, methanol and aqueous fractions of Tymus vulgaris on tracheal chains of guinea pigs were examined. The relaxant effects of four cumulative concentrations of each fraction $(0.4,0.8,1.2$ and $1.6 \mathrm{~g} \%)$ in comparison to saline as negative control and four cumulative concentrations of theophylline $(0.2,0.4,0.6$ and $0.8 \mathrm{mM})$ were examined for their relaxant effects on precontracted tracheal chains of guinea pig by $60 \mathrm{mM} \mathrm{KCl}$ (group 1) and $10 \mu \mathrm{M}$ methacholine (group 2, $\mathrm{n}=7$ for each group). In group 1, all concentrations of the n-hexane fraction and theophylline and three last concentrations $(0.8,1.2$ and $1.6 \mathrm{~g} \%)$ of dichloromethane and two higher concentrations (1.2 and $1.6 \mathrm{~g} \%$ ) of methanol fractions showed significant relaxant effects compared to that of saline $(\mathrm{p}<0.05$ to $\mathrm{p}<0.001)$. In group 2 , all concentrations of theophylline, $\mathrm{n}$-hexane and dichloromethane fractions and three concentrations $(0.8,1.2$ and $1.6 \mathrm{~g} \%)$ of methanol and two higher concentrations (1.2 and $1.6 \mathrm{~g} \%)$ of aqueous fractions showed significant relaxant effects compared to that of saline $(\mathrm{p}<0.05$ to $\mathrm{p}<0.001)$. In addition, with group 1 , the relaxant effect of all concentrations of all fractions except the $n$-hexane fraction, were significantly less than those of theophylline $(p<0.05$ to $p<0.001)$. The n-hexane fraction showed higher relaxant effect than theophylline. The relaxant effect of all concentrations of the n-hexane fraction and the three last concentrations $(0.8,1.2$ and $1.6 \mathrm{~g} \%)$ of dichloromethane and aqueous fractions were significantly greater in group 2 than in group 1 ( $p<0.05$ to $p<0.001)$. There were significant positive correlations between the relaxant effects and concentrations for theophylline and all fractions (except aqueous fraction in group 1) in both groups, but a negative correlation for the aqueous fraction in group 1 ( $p<0.05$ to $p<0.001)$. These results showed a potent relaxant effect for n-hexane and weaker relaxant effect for other fractions from Tymus vulgaris on tracheal chains of guinea pigs.
\end{abstract}

Key words: Tymus vulgaris; Fractions; Relaxant effects; Guinea pig; Trachea

\section{INTRODUCTION}

The main active constituents of Tymus vulgaris L include: terpenes, phenols, thymol, carvacrol, terpenoids, glycosides of phenolic monoterpenoids, eugenol and aliphatic alcohols, flavonoids such as thymonin, cirsilineol and 8-methoxycirsilineol, biphenyl compounds of monoterpenoid origin, caffeic and rosmarinic acids and saponins (ESCOP, 1997). Other constituents include tannins, labiatic acid, ursolic acid, and oleanolic acid. Thyme also contains apigenin, luteolin, and 6-hydroxyluteolin glycosides, as well as di-, tri-, and tetramethoxylated flavones (Mossa, 1987).

Essential oils extracted from fresh leaves and flowers can be used as aroma additives in food, pharmaceuticals, and cosmetics (Simon et al., 1999; Javanmardi et al., 2002; Senatore, 1996). Traditionally, thyme possesses various beneficial effects, e.g., antiseptic, carminative, antimicrobial, and antioxidative properties (Baranauskiene et al., 2003). Thyme extract has been used orally to treat dyspepsia and other gastrointestinal disturbances; coughs due to colds, bronchitis and pertussis, laryngitis and tonsillitis (as a gargle). Topical applications of thyme extract have been used in the treatment of minor wounds, the common cold, disorders of the oral cavity and as an antibacterial agent in oral hygiene. Both essential oil and thymol are ingredients of a number of proprietary drugs including antiseptic and healing ointments, syrups for the treatment of respiratory disorders and preparations for inhalation (Mossa, 1987). It has also been used to improve digestion (ESCOP, 1997) and to treat pertussis, stomatitis, and halitosis (Stecher, 1968).

Previous studies have shown different pharmacological effect for this plant. In vitro studies have shown that both thyme essential oil and thymol have antifungal activity against a number of fungi including Cryptococcus neoformans, Aspergillus, Saprolegnia, and Zygorhynchus species (Vollon and Chaumont, 1994; Perrucci et al., 1995; Pasteur N et al., 1995; Tantaouielaraki and Errifi, 1994). Both essential oil and thymol have antibacterial activity against Salmonella typhimurium, Staphylococcus aureus, Escherichia coli and a number of other bacterial species (Janssen et al., 1987; Juven et al., 1994). As an antibiotic, thymol is 25 times more effective than phenol, but less toxic (Czygan, 1989). The relaxant effect of this plant on tracheal and ileal smooth muscle has been shown (Meister et al., 1999; Boskabady et al., 2006; Babaei et al., 2008). The relaxant effect of other plants of this family on tracheal and ileal smooth muscle of guinea pigs has also been reported previously (Reiter and Brandt, 1985).

Therefore, in the present study, the relaxant effects of n-hexane, dichloromethane, methanol and aqueous fractions 
of $T$. vulgaris on tracheal chains of guinea pigs were examined. These fractions are different ingredients of the plant that have not been characterized in terms of composition.

\section{MATERIALS AND METHODS}

Plant and fractions

T. vulgaris was collected from the Tabas mountains (centre east region of Iran) and identified by botanists at Ferdowsi University in the city of Mashhad. A voucher specimen was preserved in the Herbarium of the School of Agriculture, Ferdowsi University (Herbarium No: 153-2613-2). Four fractions were prepared as follows (Fig. 1): $300 \mathrm{ml}$ n-hexane was added to two hundred grams of chopped, dried seeds and the solution was kept at room temperature for 48 hours. The solution was then separated by maceration and dried by a rotary evaporator at $50^{\circ} \mathrm{C}$ under reduced pressure. The same as above, dichloromethane, methanol and distilled water were respectively added to the remaining powder and extractions were carried out by maceration at room temperature for 48 hours. Finally, four different fractions including n-hexane, dichloromethane, methanol and water extracts were obtained. The $40 \mathrm{~g} \%$ solutions were prepared for all fractions by adding distilled water to dried fractions.

\section{Tissue preparation}

Guinea pigs (400-700 g, both sexes) were killed by a blow on the neck and tracheas were removed. Each trachea was cut into 10 rings (each containing 2-3 cartilaginous rings). All the rings were then cut open opposite the trachealis muscle, and sutured together to form a tracheal chain (Holroyde, 1986). Tissue was then suspended in a $20 \mathrm{ml}$ organ bath (Schuler organ bath type 809, March- Hugstetten, Germany) containing Krebs-
Henseliet solution of the following composition (mM): $\mathrm{NaCl}$ 120, $\mathrm{NaHCO}_{3} 25, \mathrm{MgSO}_{4} 0.5, \mathrm{KH}_{2} \mathrm{PO}_{4} 1.2, \mathrm{KCl} 4.72, \mathrm{CaCl}_{2} 2.5$ and dextrose 11.

The Krebs solution was maintained at $37^{\circ} \mathrm{C}$ and gassed with $95 \% \mathrm{O}_{2}$ and $5 \% \mathrm{CO}_{2}$. Tissue was suspended under an isotonic tension of $1 \mathrm{~g}$ and allowed to equilibrate for at least $1 \mathrm{~h}$ while it was washed with Krebs solution every $15 \mathrm{~min}$.

Protocols

We examined the relaxant effects of four cumulative concentrations $(0.4,0.8,1.2$ and $1.6 \mathrm{~g} \%)$ of n-hexane, dichloromethane, methanol and aqueous fractions of T. vulgaris and theophylline anhydrous (Sigma Chemical Ltd, UK) (0.2, $0.4,0.6$ and $0.8 \mathrm{mM})$ as positive control, and saline $(1 \mathrm{ml})$ as negative control. To produce the first concentration of each fraction, $0.2 \mathrm{ml}$ of $40 \mathrm{~g} \%$ was added to a $20 \mathrm{ml}$ organ bath and for other three concentrations; $0.2 \mathrm{ml}$ of $40 \mathrm{~g} \%$ was added to the organ bath respectively three times. For theophylline, 0.2 $\mathrm{ml}$ of $20 \mathrm{mM}$ concentrated solution was added to the organ bath 4 times. The consecutive volumes were added to the organ bath at five minutes intervals.

In each experiment, the effect of four cumulative concentrations from each fraction, theophylline or saline on contracted tracheal smooth muscle was measured after exposing tissue to each concentration of the solution for $5 \mathrm{~min}$. An increase in the length of tracheal chain was considered to be a relaxant (bronchodilatory) effect and expressed as a positive percentage change in proportion to the maximum contraction. A decrease in length of tracheal chain was considered as a contractile (bronchoconstrictory) effect, which was expressed as a negative percentage change (Holroyde, 1986).

The relaxant effect of different solutions was tested with two different experimental designs, ( $n=7$ for each group) as follows:

$200 \mathrm{~g}$ of seeds of $T$. vulgaris

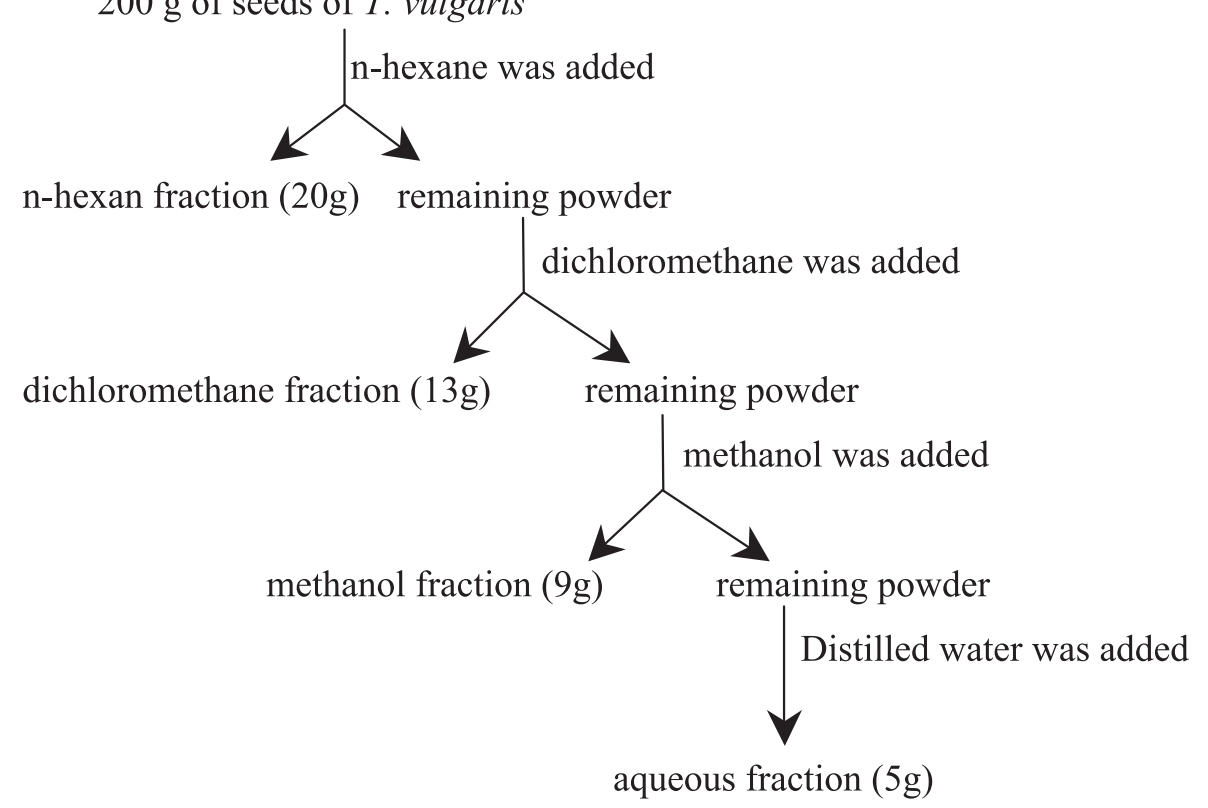

Figure 1: Separation of different fractions of the seeds of Tymus vulgaris. The numbers in grams refer to dried yield fraction. 
1. On tracheal chains contracted by $60 \mathrm{mM} \mathrm{KCl}$ (group 1 experiment).

2. On tracheal chains contracted by $10 \mu \mathrm{M}$ methacholine hydrochloride (Sigma Chemical Ltd, UK), (group 2 experiment).

The relaxant effects in two groups of experiments were examined in two different series of tracheal chains. All of the experiments were performed randomly with a $1 \mathrm{~h}$ resting period for tracheal chains between each two experiments while washing the tissues every 15 min with Krebs solution. In all experiments, responses were amplified with an amplifier (ML/118 quadribridge amp, March- Hugstetten, Germany) and recorded on power lab (ML-750, 4 channel recorder, MarchHugstetten, Germany).

\section{Statistical analysis}

All data were expressed as mean \pm SEM. Data of relaxant effects of different concentrations of each fraction were compared to the results of negative and positive controls using paired t-test. The data of relaxant effects obtained in two groups of experiments were compared using the unpaired t-test. The relaxant effects of different concentrations of four different fractions were compared to each other using ANOVA. The relaxant effect of different concentrations of four fractions and theophylline were related to their concentrations using least square regression. Significance was accepted at $\mathrm{p}<0.05$.

\section{RESULTS}

\section{Relaxant (bronchodilatory) effect}

In group 1 experiments, all concentrations of theophylline and n-hexane fraction, three last concentrations $(0.8,1.2$ and $1.6 \mathrm{~g} \%)$ of dichloromethane and two higher concentrations (1.2 and 1.6 $\mathrm{g} \%)$ of methanol fractions showed significant relaxant effects compared to that of saline $(\mathrm{p}<0.05$ to $\mathrm{p}<0.001)$. However, all concentrations of aqueous fraction showed contractile effects compared to that of saline in this group which was statistically significant for three last concentrations $(0.8,1.2$ and $1.6 \mathrm{~g} \%)$, $(\mathrm{p}<0.05)$, (Fig. 2).

In group 2 experiments, all concentrations of theophylline and $\mathrm{n}$-hexane and dichloromethane fractions, three last concentrations $(0.8,1.2$ and $1.6 \mathrm{~g} \%)$ of methanol fraction and two higher concentrations of aqueous fraction (1.2 and $1.6 \mathrm{~g} \%$ ) showed significant relaxant effects compared to that of saline ( $\mathrm{p}<0.05$ to $\mathrm{p}<0.001$ ), (Fig. 3).

Comparison of the relaxant effect of theophylline with different fractions

In both groups 1 and 2, the relaxant effect of all concentrations of dichloromethane, methanol and aqueous fractions were significantly less than those of theophylline $(\mathrm{p}<0.05$ to $\mathrm{p}<0.001)$. The relaxant effect of $\mathrm{n}$-hexane fraction was significantly higher than that of theophylline in group 2 $(\mathrm{p}<0.01$ to $\mathrm{p}<0.05)$, (Fig. 2 and 3).

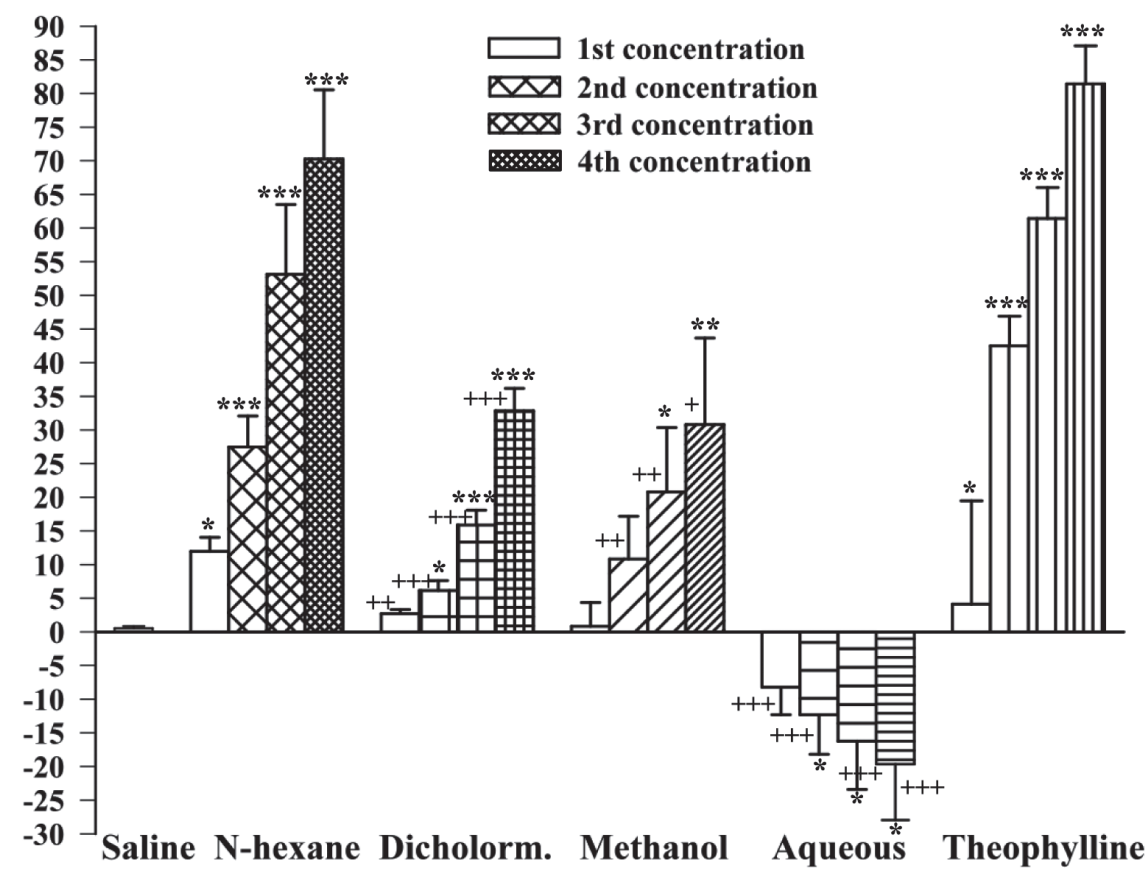

Figure 2: Relaxant effect (mean $\pm \mathrm{SEM}$ ) of four different fractions (n-hexane, dichloromethane, methanol and aqueous) from T. vulgaris in comparison with negative control (saline) and positive control (theophylline) in Group 1 experiments (contracted tracheal chains by $60 \mathrm{mM} \mathrm{KCl}, \mathrm{n}=7$ ). The four different concentrations for fractions were $0.4,0.8,1.2$ and $1.6 \mathrm{~g} \%$, and for theophylline, $0.2,0.4 .0 .6$ and 0.8 $\mathrm{mM}$. Dichlorom.: dichloromethane. Statistical differences between the effect of fractions and theophylline with that of saline; $*: p<0.05, * *$ : $\mathrm{p}<0.01$ and ${ }^{* * *}: \mathrm{p}<0.001$. Statistical differences between the effect of fractions and theophylline; $+: \mathrm{p}<0.05,++: \mathrm{p}<0.01$ and $+++: \mathrm{p}<0.001$. 


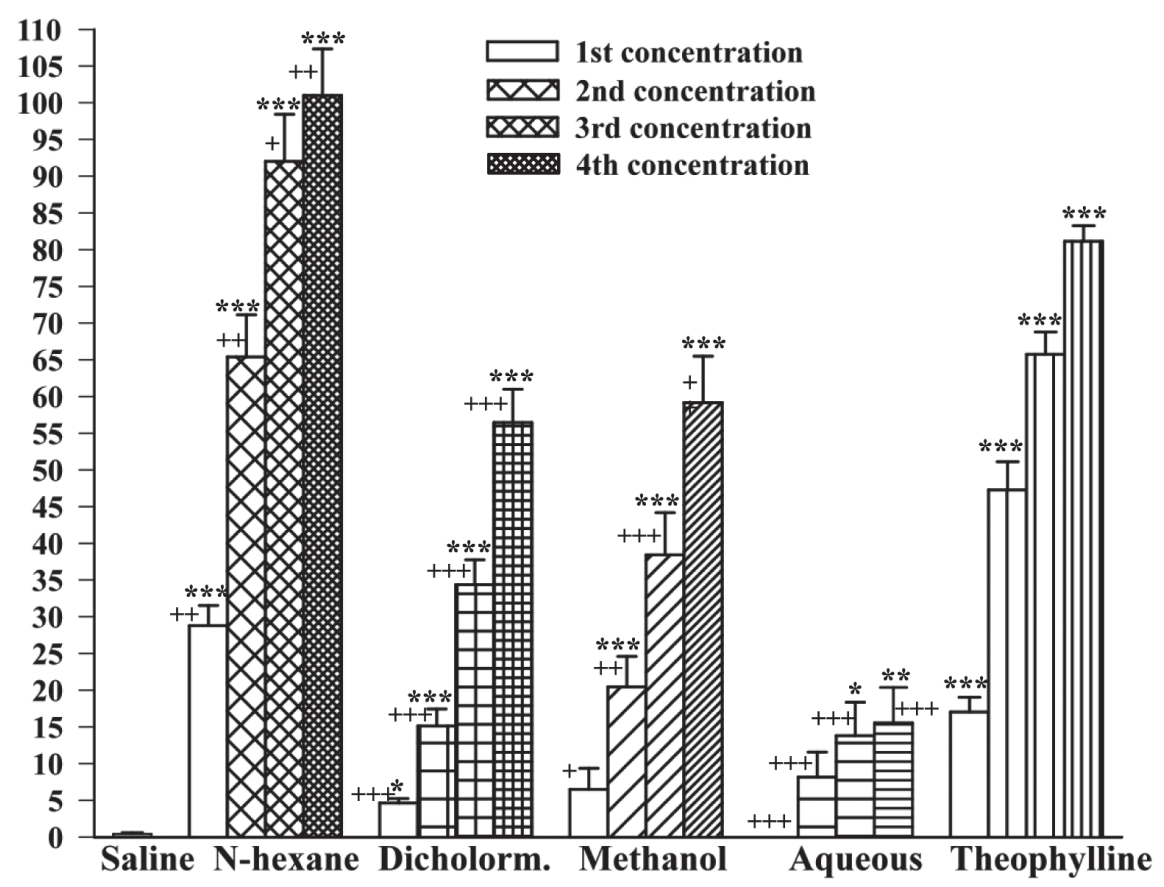

Figure 3: Relaxant effect (mean $\pm S E M)$ of four different fractions ( $n$-hexane, dichloromethane, methanol and aqueous) from $T$. vulgaris in comparison to negative control (saline) and positive control (theophylline) in Group 2 experiments (contracted tracheal chains by $10 \mathrm{mM}$ methacholie, $\mathrm{n}=7$ ). The four different concentrations for fractions were $0.4,0.8,1.2$ and $1.6 \mathrm{~g} \%$, and for theophylline, $0.2,0.4$. 0.6 and 0.8 mM. Dichlorom.: dichloromethane. Statistical differences between the effect of fractions and theophylline with that of saline; $*$ : $<<0.05, * *$ : $\mathrm{p}<0.01$ and $* * *: \mathrm{p}<0.001$. Statistical differences between the effect of fractions and theophylline; $+: \mathrm{p}<0.05,++: \mathrm{p}<0.01$ and $+++: \mathrm{p}<0.001$.

\section{Comparison of the relaxant effect of different fractions}

In both groups, the relaxant effects of all concentrations of the n-hexan fraction were significantly greater than those of others $(p<0.01$ to $p<0.001)$. In addition, the relaxant effects of all concentrations of aqueous fractions were significantly lower than those of other fractions in both groups $(\mathrm{p}<0.05$ to $\mathrm{p}<0.001)$.

\section{Comparison of the relaxant effect between two groups of experiments}

The relaxant effect of all concentrations of the n-hexane fraction and the three last concentrations $(0.8,1.2$ and $1.6 \mathrm{~g} \%)$ of dichloromethane and aqueous fractions were significantly greater in group 2 than in group 1 experiments $(p<0.01$ to $\mathrm{p}<0.001)$. However, there was no significant difference in the relaxant effect of different concentrations of the theophylline and methanol fraction between two groups (Fig. 4).

\section{Correlation between concentrations of solutions and their relaxant effect}

There were significant positive correlations between the relaxant effects and concentrations for theophylline and all fractions (except aqueous fraction in group 1) in both groups $(p<0.05$ to $p<0.001)$. However, the correlation between the relaxant effects and concentrations for aqueous fraction in group 1 was not significant (Table 1).

\section{DISCUSSION}

In this study, the relaxant effects of four different fractions of $T$. vulgaris in comparison to saline as negative control and theophylline as positive control were studied. In group 1 experiment (contracted tracheal chains by $\mathrm{KCl}$ ), all fractions (except aqueous fraction) and theophylline showed relaxant effect on tracheal smooth muscle. The relaxant effects of dichloromethane and methanol fractions were significantly less than that of theophylline. However almost, all fractions of T. vulgaris showed relatively potent relaxant effects compared with the effect of saline. In group 2 experiments, the relaxant effects of dichloromethane, methanol and aqueous fractions were significantly lower than that of theophylline but n-hexane fraction showed a relaxant effect higher than that of theophylline. Theophylline is a non-specific relaxant drug for airways with different possible mechanisms including inhibition of phosphodiesterase to increase intracellular cAMP levels (Rabe et al. 1995) and nonselective adenosine receptor antagonist effect (Daly et al. 1987). Therefore, it was used as a positive control in the present study. There were positive correlations between concentrations and the relaxant effects of all fractions in both groups of experiments. The contractions obtained by $10 \mu \mathrm{M} \mathrm{MC}$ and $60 \mathrm{mM} \mathrm{KCl}$ were $70 \%$ of maximum contraction by the corresponding substance. Therefore, the comparison of the relaxant effects of different solutions in precontracted tracheal muscle by two substances is valid. 


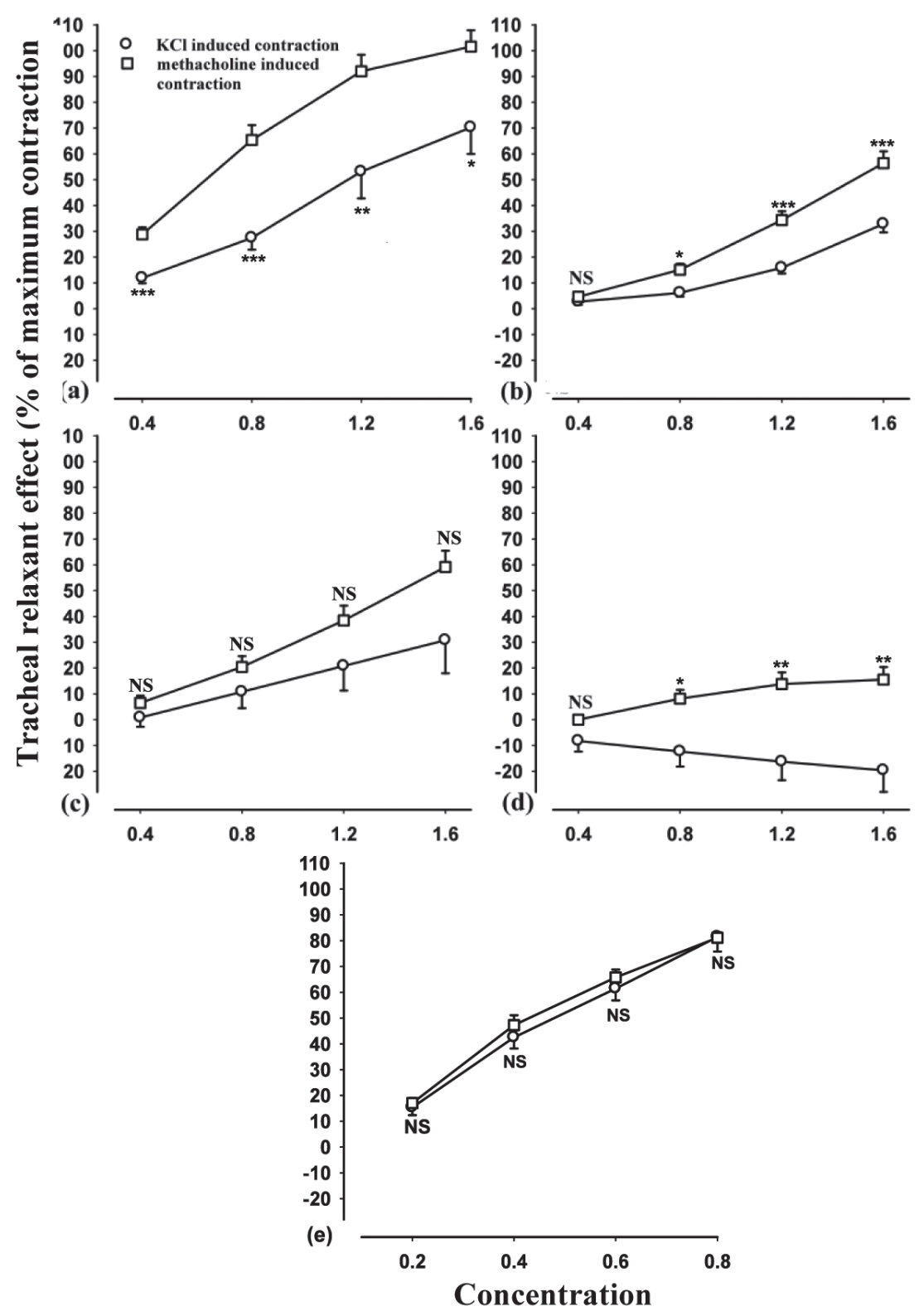

Figure 4: Concentration response curves of the relaxant effect of $n$-hexane (a), dichloromethane (b), methanol (c) and aqueous fractions (d) from T. vulgaris and theophylline (e) in two groups of experiments. Group 1: $\mathrm{KCl}$ induced contraction of tracheal chains (o) and Group 2: methacholine induced contraction of tracheal chains, ( $n=7$ for each groups). Concentrations for fractions were $0.4,0.8,1.2$ and $1.6 \mathrm{~g} \%$, and for theophylline, 0.2, 0.4. 0.6 and $0.8 \mathrm{mM}$. Statistical differences in the relaxant effect of different concentrations of each fraction of Group 1 and those of Group 2; NS: non-significant difference, ${ }^{*} ; \mathrm{p}<0.05,{ }^{* *} ; \mathrm{p}<0.01,{ }^{* *} ; \mathrm{p}<0.001$. The concentration unit for fractions was $\mathrm{g} \%$, and for theophylline, $\mathrm{mM}$.

TABLE 1

Correlation ( $r$ ) among the relaxant effects of four different fractions (n-hexane, dichloromethane, methanol and aqueous) from $T$. vulgaris and theophylline with their concentrations in two groups of experiments

\begin{tabular}{lcccccccccc}
\hline \multirow{2}{*}{$\begin{array}{l}\text { Different } \\
\text { solutions }\end{array}$} & \multicolumn{2}{c}{$\mathrm{n}$-hexane fraction } & \multicolumn{2}{c}{ Dichloromethane fraction } & \multicolumn{2}{c}{ Methanol fraction } & \multicolumn{2}{c}{ Aqueous fraction } & \multicolumn{2}{c}{ Theophylline } \\
\cline { 2 - 11 } & $\mathrm{R}$ & $\mathrm{P}$ value & $\mathrm{R}$ & $\mathrm{P}$ value & $\mathrm{r}$ & $\mathrm{P}$ value & $\mathrm{R}$ & $\mathrm{P}$ value & $\mathrm{r}$ & $\mathrm{P}$ value \\
\hline Group 1 & 0.762 & $\mathrm{p}<0.001$ & 0.869 & $\mathrm{p}<0.001$ & 0.460 & $\mathrm{p}<0.05$ & -0.257 & $\mathrm{NS}$ & 0.908 & $\mathrm{p}<0.001$ \\
Group 2 & 0.876 & $\mathrm{p}<0.001$ & 0.920 & $\mathrm{p}<0.001$ & 0.849 & $\mathrm{p}<0.001$ & 0.534 & $\mathrm{p}<0.01$ & 0.947 & $\mathrm{p}<0.001$ \\
\hline
\end{tabular}


The results of this study confirmed those of Meister et al. (1999), Boskabady et al. (2006), Babaei et al. (2008) and Reiter and Brandt (1985) indicating relaxant effect of this plant on tracheal and ileal smooth muscles. In our previous study, the relaxant effect of macerated and aqueous (Soxhlet extracted) extracts of the plant was studied (Boskabady et al. 2006). However, the present work studied the effect of four different fractions of the plant that were different in composition. The results of the present study showed that n-hexane is the main fraction of the plant responsible for the relaxant effect of the plant and aqueous fraction showed the least relaxant effect. Therefore, the results showed that mainly lipid soluble ingredients of the plant are responsible for its relaxant effect.

The spasmolytic and antitussive activity of thyme has been most often attributed to its constituents: thymol and carvacrol, which make up a large percentage of the volatile oil (Meister et al., 1999). Although these compounds have been shown to prevent contractions induced in the ileum and the trachea of the guinea pig, by histamine, acetylcholine and other reagents, the concentration of phenolics in aqueous preparations of the drug is insufficient to account for this activity (Van Den Broucke, 1980; Van Den Broucke and Lemli, 1981). Our previous study (Boskabady and Jandaghi, 2003) showed a potent effect for carvacol, which is one of the constituents of $T$. vulgaris. Therefore, the carvacol content of the plant may be responsible for its relaxant effect on tracheal chains. Experimental evidence also suggests that the in vitro spasmolytic activity of thyme preparations is due to the presence of polymethoxy flavones (Van Den Broucke and Lemli, 1983). In vitro studies have shown that flavones and thyme extracts inhibit responses to agonists of specific receptors such as acetylcholine, histamine and L-norepinephrine, as well as agents whose actions do not require specific receptors, such as barium chloride. The flavones of thyme were found to act as noncompetitive and non-specific antagonists. They were also shown to be $\mathrm{Ca}_{2}-$ antagonists and musculotropic agents that act directly on smooth muscle (Van Den Broucke and Lemli, 1983).

The relaxant effect of the plant is not due to its main constituent, thymol because another study we conducted failed to show any relaxant effect for thymol on tracheal chains of guinea pig (Boskabady et al., 1998).

Methacholine caused contraction by stimulating muscarinic receptors. However, $\mathrm{KCl}$ causes depolarisation of the muscle fibbers leading to increase of sarcopelasmic calcium concentration and contraction. Therefore, the results of the present study may indicate that the relaxant effect of different fractions from $T$. vulgaris on tracheal chains of guinea pigs might be produced due to their inhibitory effect on muscarinic receptors because, the relaxant effect on methacholine induced contraction was greater than $\mathrm{KCl}$ induced contraction. In addition, the relaxant effect of muscarinic receptors has been documented previously (Leonards et al., 1992). However, due to the existence of relaxant effect of relaxant effect of $\mathrm{n}$-hexane, dichloromethane and methanol fraction on $\mathrm{KCl}$ induced contraction of tracheal muscle (group 1); these fractions may have inhibitory effect on calcium channels and/ or opening effect on potassium channels. In fact, the relaxant effect of potassium channels openers (Buckle et al., 1993; Perez-Guerrero et al., 1997) and calcium channel blockers (Miyahara et al., 1993; McCaig and DeJonckeere, 1993) has been shown. In addition, it is well known that $\mathrm{KCl}$ can affect calcium channels. However, with regard to the potent relaxant effect of $\beta$-adrenergic receptors (Lronards et al., 1992; Buckle et al., 1993), stimulator effect of fractions of the plant on $\beta_{2}$ adrenoceptors could not be excluded by the results of this study. Therefore, more studies are required to reveal the different therapeutic effects, effective substance(s), and extract mechanism(s) of relaxant effect of T. vulgaris.

A secretomotoric activity has also been suggested for thyme oil, which has been associated with a saponin extract from $T$. vulgaris (Vollmer, 1932). Stimulation of ciliary movements in the pharynx mucosa of frogs treated with diluted solutions of thyme oil, thymol or carvacrol has also been reported (Freytag, 1933). Furthermore, an increase in mucus secretion of the bronchi after treatment with thyme extracts has been observed (Schilf, 1932). Muller-Limmroth and Frohlich (1980) have suggested a protective effect on mucous layers in the hypopharynx and spasmolytic, secretolytic and bactericide effects. In contrast, Lemiere et al (1996) have reported the occupational asthma due to the exposure of subjects to thyme. The antioxidant effects of this plant have been also shown. Therefore, this plant may have theraputic effect on respiatory diseases (Haraguchi et al., 1996). It was also shown that the thyme extract may help in the treatment of diseases related to endothelin hyper-reagibility of the bronchus system, such as asthma and COPD (chronic obstructive pulmonary disease), but thymol is not involved in this effect (Engelbertz et al., 2008).

In the present study, 4 concentrations of each fractions and positive control (theophylline) were used to evaluate the concentration dependency of the relaxant effect of each solution. A complete dose-response curve, achievement of Emax and measurement of $\mathrm{EC}_{50}$ values were only valid for a pure substance that affects a certain receptor. For an unknown solution such as fractions used in the present study the examination of the effect of few concentrations is valid. In fact, in further studies the pure effective substance of each fraction needs to be identified and its complete dose-response curve, Emax and $\mathrm{EC}_{50}$ should be measured. The aim of the present study was to evaluate the relaxant effect of different fractions of $T$. vulgaris. However, the exact mechanism(s) of the relaxant effects of different fractions and their effective substances such as the effect of different fractions on calcium channels should be examined in further studies.

As is made clear in the Method section (Plant and fractions), all fractions were dried (the solvents were removed). Therefore, the effects of the vehicles n-hexane, dichloromethane and methanol were not contributed in the observed relaxant effects.

Nonploar substances, lipids and essential oil are extracted in $n$-hexane fraction, polar terfenadines is extracted in dichlormethan fraction, glycosides and saponins are extracted in methanol fraction and carbohydrates and solutes are extracted in aqueous fraction. Considering the best effect of volatile oil-containing n-hexane fraction, the observed relaxant activity may be attributed to mainly the non-polar constituents of the plant such as carvacrol and thymol. In fact, the relatively potent relaxant effect of carvacrol on tracheal chains was observed in our previous study, which supports the findings of the present study (Boskabady and Jandaghi, 2003). However, the relaxant effects of other fractions, especially dichlormethan and methanol fractions indicated that other ingredients of the plant also contributed to its relaxant effect on tracheal smooth muscle. 
In conclusion, the results of this study indicate a potent relaxant effect for n-hexane and weaker relaxant effect for other fractions from $T$. vulgaris on tracheal chains of guinea pigs. The weakest relaxant effect was seen for aquous fractions.

\section{ACKNOWLEDGEMENT}

This study was financially supported by the Research Council of Mashhad University of Medical Sciences. The authors would also like to thank Mr Ahmad Nezami, botanist, for identification of the plant and Dr. A. Delazar for his help in fractionation of the plant.

\section{REFERENCES}

BABAEI M, ABARGHOEI ME, ANSARI R, VAFAEI AA, TAHERIAN AA, AKHAVAN MM, TOUSSY G, MOUSAVI S (2008) Antispasmodic effect of hydroalcoholic extract of Thymus vulgaris on the guinea-pig ileum. Nat Prod Res 22: 1143-1150.

BARANAUSKIENE R, VENSKUTONIS PR,VISKELIS P, DAMBRAUSKIENE $E$ (2003). Influence of nitrogen fertilizers on the yield and composition of thyme (Thymus vulgaris). J Agri Food Chem 51: 7751-7758.

BOSKABADY MH, ASLANI MR, KIANI S (2006) Relaxant effects of Tymus volgari on guinea pig tracheal chains and its possible mechanism(s). Phytother Res 20: 28-33.

BOSKABADY MH, JANDAGHI P (2003) Relaxant effect of carvacrol on guinea pig tracheal chainsand its possible mechanisms. Pharmazie 58: 661-663.

BOSKABADY MH, RAKHSHANDAH H, MOETAMEDSHARIATI V (1998) Bronchodilatory and anticholinergic effects of Carum copticum on isolated guinea pig tracheal chains. Med J I R Iran 11: 329-334.

BUCKLE DR, ARCH JRS, BOERING NE, FOSTER KA, TAYLOR JF, TAYLOR SG, SHAW DJ (1993) Relaxation effect of potassium channel activators BRL 38227 and Pinacidil on guinea pig and human airway smooth muscle, and blockade of their effects by libenclamide and BRL 31660 . Pulmon Pharmacol 6: 77-86.

CZYGAN C-F (1989) Thymian, Thymi Herba. In: Wichtl M. ed. Teedrogen, 2nd ed. Stuttgart, Wissenschaftliche Verlagsgesellschaft: 498-500.

DALY JW, JACOBSON KA, UKENA D. (1987). Adenosine receptors: development of selective agonists and antagonists. Prog Clin Biol Res. 230: 41-63.

ENGELBERTZ J, SCHWENK T, KINZINGER U, SCHIERSTEDT D, VERSPOHL EJ (2008) Thyme extract, but not thymol, inhibits endothelininduced contractions of isolated rat trachea. Planta Med 74: 1436-1440.

ESCOP (1997) "Thymi herba." Monographs on the Medicinal Uses of Plant Drugs. Exeter, U.K.: European Scientific Cooperative on Phytotherapy.

FREYTAG A. ber den Einflu von (1933) Thymianl, Thymol und Carvacrol auf die Flimmerbewegung. Pflügers Archiv, Eur J Physiol 232: 346- 350.

HARAGUCHI H., SAITO T., ISHIKAWA H., DATE H., KATAOKA S., TAMURA Y, MIZUTANI K (1996) Antiperoxidative components in Thymus vulgaris. Planta Med 62: 217-221.

HOLROYDE MC (1986) The influence of epithelium on the responsiveness of guinea pig isolated trachea. Br J Pharmacol 87: 501-507.

JANSSEN AM, SCHEFFER JJC, BAERHEIM-SVENDSEN A (1987) Antimicrobial activity of essential oils: A1976-1986 literature review. Aspects of the test methods. Planta Med 53: 395-398.

JAVANMARDI J, KHALIGHI A, KASHI A, BAIS HP, VIVANCO JM (2002) Chemical characterization of basil (Ocimum basilicum L.) found in local accessions and used in traditional medicines in Iran. J Agri Food Chem 50: 5878-5883.

JUVEN BJ, KANNER J, SCHVED F, WEISSSLOWICZ H (1994) Factors that interact with the antibacterial action of thyme essential oil and its active constituents. J Appl Bacteriol 76:626-631.

LEMIERE C, CARTIER A, LEHRER SB, MALO JL (1996) Occupational asthma caused by aromatic herbs. Allergy 51: 647-649.
LEONARDS B, RAMPART M, HERMAN AG (1992) Selective M $_{3}$ muscarinic receptors inhibit smooth muscle contraction in rabit trachea without increasing the release of acetylcholine. J Pharmacol Exp Ther 263: 773-770.

MCCAIG D, DEJONCKEERE S (1993) Effect of two $\mathrm{Ca}^{2+}$ modulator in normal and albumin sensitised guinea pig trachea. Eur J Pharmacol 249: 53-63.

MEISTER A, BERNHARDT G, CHRISTOFFEL V, BUSCHAUER A (1999) Antispasmodic activity of Thymus vulgaris extract on the isolated guinea-pig trachea: discrimination between drug and ethanol effects. Planta Med 65: 512-516.

MIYAHARA Y, KIZAWA Y, SANO M, MURAKAMI H (1993) Effect of organic and inorganic $\mathrm{Ca}^{2+}$ antagonists on acetylcholine induced contraction in molluscan (Mytilus edulis) smooth muscle. Gen Pharmacol 24: 1419-1423.

MOSSA JS, AL-YAHYA MA, AL-MESHAL IA (1987) Medicinal plants of Saudi Arabia. Riyadh, Saudi Arabia, King Saud University Libraries 1 .

MULLER-LIMMROTH W, FROHLICH HH (1980) Effect of various phytotherapeutic expectorants on mucociliary transport. Fortschr Med 98: 95-101.

PASTEUR N, MENASHEROV M, RAVID U, JUVEN B (1995) Antifungal activity of oregano and thyme essential oils applied as fumigants against fungi attacking stored grain. J food protection 58: 81- 85 .

PEREZ-GUERRERO C, SUAREZ J, HERRERA MD, MARHUNNDA E (1997) Spasmolytic effect of tetrazepam on rat duodenum and guinea pig ileum. Pharmacol Res 35: 493-494.

PERRUCCI S CECCHINI S, PRETTI C, VARRIALE COGNETTI AM, MACCHIONI G, FLAMINI G, CIONI PL (1995) In vitro antimycotic activity of some natural products against Saprolegnia ferax. Phytother Res 9: 147-149.

RABE, KF, MAGNUSSEN, H, DENT, G (1995) Theophylline and selective PDE inhibitors as bronchodilators and smooth muscle relaxants. Eur Respir J 8: 637-642.

REITER M, BRANDT W (1985) Relaxant effects on tracheal and ileal smooth muscles of the guinea pig. Arzneimittelforschung 35: 408-414

SCHIIF F, EINFLUSS VON (1932) Azetylcholin, Adrenalin, Histamin und Thymianextrakt auf die. Bronchialschleimhautsekretion; zugleich ein Beitrag zur Messung der Bronchialschleimhautsekretion. NaunynSchmiedebergs Archiv für Pharmakologie 166: 22-25.

SENATORE F (1996) Influence of harvesting time on yield and composition of the essential oil of a thyme (Thymus pulegioides L.) growing wild in Campania (southern Italy). J Agri Food Chem 44: 1327-1332.

SIMON JE, MORALES MR, PHIPPEN WB,VIEIRA RF, HAO Z (1999) A source of aroma compounds and a popular culinary and ornamental herb. In J Janick (Ed.), Perspectives on new crops and new uses (pp.499505). Alexandria,VA: ASHS Press.

STECHER PG (1968) The Merck Index: An Encyclopedia of Chemicals and Drugs, $8^{\text {th }}$ ed.

Rahway, N.J.: Merck \& Co., Inc.

TANTAOUIELARAKI A, ERRIFI A (1994) Antifungal activity of essential oils when associated with sodium chloride or fatty acids. Grasas-yaceites 45: 363-369.

VAN DEN BROUCKE CO, LEMLI JA (1983) Spasmolytic activity of the flavonoids from Thymus vulgaris. Pharm Weekbl 5: 9-14.

VAN DEN BROUCKE CO, LEMLI JA (1981) Pharmalogical and chemical investigation of thyme liquid extracts. Planta Medica 41: 129-135.

VAN DEN BROUCKE CO (1980) Chemical and pharmacological investigation on Thymi herba and its liquid extracts. Planta Med 39: 253-254.

VOLLMER H (1932) Untersuchungen über Expektorantien und den Mechanismus ihrer Wirkung. 21Klinische Wochenschrift 11: 590-595.

VOLLON C, CHAUMONT JP (1994) Antifungal properties of essential oils and their main components upon Cryptococcus neoformans. Mycopathol 128: 151-153. 
